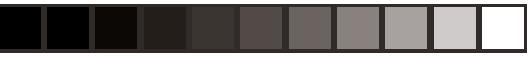

\title{
JESPER SØRENSEN
}

\section{DEN MAGISKE ILLUSION?}

\author{
En kognitiv tilgang til magiske ritualer ${ }^{1}$
}

Begrebet „magi“ har været udsat for voldsom kritik i antropologien og religionsvidenskaben. Det er blevet beskyldt for ikke blot at beskrive en illusion opfattet som virkelighed af primitive folk, men for at være en analytisk illusion, med hvilken vestlige antropologer systematisk har misforstået ikke-vestlige religioner. Spørgsmålet er ikke længere, hvori magien består, men om „magi“ blot er et analytisk blændværk, en forskningshistorisk dinosaur, der for længst burde være gået til grunde i postkolonialismens og postmodernismens meteorstorm. Ifølge de kritiske teorier er magi jo blot en etnocentrisk betegnelse for Det Andet, en kategori beregnet til at nedgøre andre religioner og deres praksis, og en metode til yderligere at udgrænse i forvejen marginaliserede grupper, det være sig politisk, økonomisk eller religiøst. Begrebet beskrives af kritikere som intimt forbundet med den vestlige antropologis, sociologis og religionsvidenskabs primitivitetsopfattelse, ifølge hvilken magi er en rituel handling, der, på basis af en inferiør og primitiv verdensopfattelse, tror sig i stand til at manipulere den fysiske verden. Magi opfattes således som en pseudoteknologi, Frazers „,bastard sister of science“ (Frazer 1993:50), der på et tidligt og derfor primitivt tidspunkt i menneskets udvikling gav individet en intellektuel og emotionel følelse af kontrol over ellers ukontrollerbare begivenheder såsom sygdom, vejrlig og adgang til føde. Underforstået i denne anskuelse ligger naturligvis, ,at vi ved bedre" med vores videnskabelige tilgang. Dette afvises naturligvis skarpt af den postmoderne og postkoloniale kritik, der i stedet opfatter fors $\emptyset \mathrm{g}$ på at manipulere verden som udtryk for magtrelationer, om kamp om adgang til viden og magt til at sætte, hvori denne viden overhovedet består (fx Taussig 1993). Det, som vestlige forskere har klassificeret som magi, er således nærmere en beskrivelse af lokale kulturelle betydningssystemer, der har til formål at regulere det enkelte individs tilgang til verden, og som ikke principielt adskiller sig fra den vestlige videnskab. Den postkoloniale og postmoderne kritik bevæger sig således fra det epistemologiske, det vil sige spørgsmålet om kategoriens historie og konkrete brug, til det politiske, det vil sige til spørgsmålet om kategoriens rolle i en videnssociologi baseret på magt.

Brugen af begrebet „magi“ har dog også været problematiseret og kritiseret fra en mere empirisk-historisk position. Magi opfattes her som et polemisk begreb i den vestlige kulturhistorie siden antikken, primært brugt til at definere De Andre som eksotiske, uudviklede og farlige barbarer med kultiske skikke, der med dæmoners og andre onde 
kræfters hjælp søger at kontrollere verden og ødelægge livet for de rettroende og civiliserede. Først i den antikke verden, hvor selv kristne må finde sig i at blive omtalt som magikere, der ødelægger de rettroendes ritualer med deres magiske kunster (Rothstein 1997). Senere er det de kristne selv, der definerer De Andre som magikere, det vil sige som kættere i forhold til den sande, universelle lære. Interessant nok ender vores kulturhistoriske vue med at termen vendes indad, og bliver et radikaliseret polemisk begreb brugt af de kirkelige reformatorer mod paven og katolicismen. ${ }^{2}$ I denne radikalisering finder vi et forhold, der får betydning for den senere brug af begrebet. Da protestanter og katolikker overvejende har fælles religiøse begreber og trosforestillinger, forbindes magi nu i stedet med en forkert udførelse af og dogmatik omkring ritualer. Magi er den overdrevne fokus på ritual efficacitet, altså det forhold at ritualet bliver tilskrevet en virkning, hvilket anses for at fjerne fokus fra selve indholdet af de religiøse forestillinger og troens inderlighed. Magi spiller således rollen som polemisk begreb i distinktionen mellem inderliggjort tro, det vil sige ,religion“, på den ene side og overfladisk rituel handling, det vil sige „magi“, på den anden. Det er dette magibegreb, udspændt i et modsætningsforhold mellem tro og handling, der er udgangspunktet for de victorianske antropologer, der som Tylor og Frazer ser det som deres ypperste mission at kortlægge de kulturelle manifestationers relative placering i den kulturelle evolution. Så selvom både Tylor og Frazer, som de intellektualister de er, beskriver magi som udtryk for fejlapplikation af en bestemt intellektuel proces, nemlig tankens associationer, sidder de alligevel fast i forestillingen om, at magi er det praktiske og tekniske fors $\emptyset \mathrm{g}$ på at forstå og kontrollere verden, mens religion er individets blinde underkastelse sig guden, som et rent trosforhold. Dikotomien mellem religion og magi undergår diverse forvandlinger i den følgende tid fra Mauss og Huberts (1950) kontrastering af den negative magi over for den positive religion, over Malinowskis (1935) instrumentelle og kortsigtede ritualer baseret på en pragmatisk tilgang til verden, til Lévi-Strauss, hvor ringen sluttes tilbage til Tylor, og magi igen forstås som baseret på en analogi fra naturen til mennesket, i modsætning til religionens antropomorfisme (Lévi-Strauss 1994 [1962]:222). Dette er naturligvis en grov forenkling af en kompliceret forskningshistorie, og pointen er udelukkende at pege på det forhold, at alle mere eller mindre ureflekteret opretholder dikotomien mellem magi og religion på samme analytiske niveau. En grov syntese af de forskellige positioner vil således afsløre et generelt magibegreb, der dækker over fænomener som individuel, instrumental, målrettet, automatisk effekt, handlingsbaseret og illusorisk over for religion som social, værdibaseret, symbolsk (i modsætning til instrumental), irrationel, intentionel og trosbaseret, hvorfor den ikke kan beskrives som sand eller falsk.

Set i dette perspektiv, og med den postmoderne og postkoloniale kritik i baghånden, kan der måske være gode grunde til at kaste begrebet på den forskningshistoriske mødding og udelukkende grave det frem som et underholdende men oplysende kuriosum, hvor nye studerende med gysen kan se det som et eksempel på en heldigvis svunden tids forblændende kategorier. For vi ved bedre! Dernæst kan vi så tage fat i begrebet ,religion“, og senere „ritualer“, „myte“, „kosmologi“" og så fremdeles, indtil vi har et historisk og ideologisk rent sprog, som enten er rent deskriptivt (vi bruger religionernes egne kategorier) eller uforståeligt (vi benytter udelukkende nye kategorier uden at definere disse ved hjælp af de gamle) eller begge dele. Nu vil nogle måske mene, at ,magi“ er et særligt belastet begreb på grund af dets historie som polemisk instrument, men jeg er overbevist om, at går vi først i gang, skal vi nok finde tilsvarende mængder belastende 

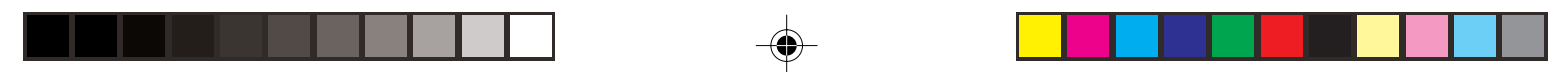

forhold ved de andre begreber. Det ændrer bare ikke ved det faktum, at de fænomener, som man prøver at fange ved hjælp af forskellige kategorier, jo ikke lader sig forklare eller fortolke ved blot at kritisere de gamle kategorier. Dekonstruktion forklarer i sig selv intet, og fænomener, der traditionelt er dækket af en given kategori, ophører ikke med at eksistere, blot fordi jeg ikke bryder mig om denne klassiske kategori. Jeg bliver ikke klogere på den praksis, at et individ stikker en nål i en dukke påført en persons hår, ved blot $i k k e$ at kalde det magi. Her kan det være nyttigt at huske på, at generelle kategorier, som „magi“, „religion“ og „myte“, ikke er deskriptive begreber, der dækker en naturlig klasse af afgrænsede elementer i verden, men derimod analytiske begreber, der, når de løsrives dagligsproget, benyttes af en observat $\varnothing r$ til at beskrive en bestemt klasse af observerede fænomener som forskellig fra andre fænomener. Begreberne indgår derved i en eller flere discipliners terminologiske inventar og muliggør, at vi kan tale sammen med en formodning om, at vi henviser til bare nogenlunde det samme.

Jeg finder, at det er muligt at redefinere begrebet ,magi“ til at blive en sådan akademisk kategori. Det kan ikke gøres ved at lave teorier om magi $i$ sig selv, men ved at lave teorier om de fænomener, man underkaster denne analytiske kategori. Hermed mister modsætningsforholdet til begrebet, ,religion“" sin relevans, da det ligeledes ikke kan være basis for teoridannelse i sig selv, men må forklares og fortolkes på baggrund af teorier om de fænomener, der omfattes af denne kategori. Dette fører mig til en mere positiv vurdering af behandlingen af magi, som den findes i den antropologiske og religionsvidenskabelige forskningshistorie. For hvad er det, de peger på, disse forgængere i studiet af eksotiske ritualer og fremmede sæder og skikke? De peger på, at visse ritualer synes styret af sympatetiske forbindelser baseret på lighed og berøring. De peger på mange ritualers instrumentale karakter, at man udfører et ritual for faktisk at opnå noget konkret. De peger på visse ritualers ekstremt formalistiske karakter, hvor ét fejltrin ikke blot ødelægger ritualet, men medfører uønskede resultater. De peger på individuelle ritualformer, der ikke nødvendigvis har almuens bedste som mål. De peger på, at visse typer af ritualer og trosforestillinger i alle samfund stigmatiseres af majoriteten som farlig, undergravende og dæmonisk. Og jeg kunne blive ved. Kort sagt er der masser af interessante fænomener beskrevet under kategorien „magi“, der fortjener vores interesse, men som klassiske fremstillinger af religion ikke synes at dække endsige interessere sig for. $\mathrm{Nu}$ kan det måske lyde som et impressionistisk kludetæppe af fænomener uden nogen indbyrdes sammenhæng. Og det er det måske også. Men deri ligner det blot andre af vore meget overordnede og generelle analytiske termer, der ligeledes synes at omfatte en sand kakofoni af forskellige fænomener - tænk blot på begrebet ,religion“. Min fornemmelse er dog, at hvis man forsøger at gribe fat i ét enkelt eller et par af disse fænomener, vil der måske vise sig en større sammenhæng, end man havde regnet med, da man begyndte sin undersøgelse.

Lidt provokerende kan man påstå, at næsten alle teoridannelser synes at falde tilbage på en eller anden form for psykologisk teori. Hvad enten det er misforstået brug af normale tanke-associationer, enkeltindividets behov og mulighed for at hævde sig og få prestige, individets behov for sikkerhed under udførelse af fiskeri og landbrug, den vilde tankes reinterpretation af samfundets basale symboler eller traditionens krav til individuel handling. Alle disse teorier grundes på en psykologisk teori om, hvorfor enkeltindivider udfører disse typer rituelle handlinger. Fokus er på det individuelle, det instrumentale, det følelsesmæssige og det symbolske, hvorfor en teori om menneskets måde at er- 
kende og erfare sin verden på er, om ikke eksplicit, så implicit til stede. Og det bringer mig til den anden centrale term i min titel, kognition.

\section{Kognition}

Der findes næsten lige så mange forskellige kognitive teorier, som der er videnskabsmænd og -kvinder, der beskæftiger sig med området. Og de er indbyrdes rygende uenige. Det er vigtigt at pege på dette forhold, da der er en tendens til rubricere kognitive tilgange til studiet af religion under én hat eksemplificeret ved Lawson og McCauley (1990) og Pascal Boyer (fx 1994). Der er dog væsentlige forskelle på deres tilgange, og de benytter oven i købet kun et lille spektrum af de kognitive teoridannelser, der på en eller anden måde berører vores interesseområde. Det, der binder kognitionsforskningen sammen på tværs af meget fundamentale forskelle, er troen på, at studiet af den måde, hvorpå det enkelte individ forstår sin verden, lærer, organiserer viden og skaber betydning, danner et selvstændigt deskriptivt niveau, om hvilket vi kan sige noget. Kognition er på den ene side begrænset af menneskets fysiske hardware. Man kan ikke opstille kognitive modeller, der må bedømmes som umulige i forhold til vor viden om hjernen og dens udvikling og funktion. Dette er ikke en neurologisk reduktionisme, da mange, inklusiv mig selv, vil hævde, at man ikke kan slutte den anden vej! Beskrivelsen af menneskets neuronale system kan udelukkende fortælle os noget om muligheder og begrænsninger for det kognitive system, men ikke om systemets endelige udformning. Den anden begrænsning er omverdenens indflydelse på de kognitive systemer. Hvordan påvirker ikke kun den fysiske verden, men også sprog og andre kulturelle fænomener vores kognitive system. Ved dette spørgsmål skilles vandene. Er kultur udelukkende et epifænomen, et mere eller mindre tilfældigt biprodukt, der kan forklares ved henvisning til individers kognition, eller dannes der kulturelle, materielt udtrykte systemer, der naturligvis er kompatible med vores kognitive system, men som ikke udtømmende kan forklares på dette niveau. Det tror jeg, men det er en heftig debat centreret omkring spørgsmålet om ,downwards causation“".

Hvad indebærer det så for studiet af kulturelle fænomener generelt og mere specifikt studiet af religion og magi at anskue de betegnede fænomener som udtryk for menneskets kognitive systemer, spændt ud som de er mellem på den ene side biologiske begrænsninger og muligheder, og på den anden side kulturelle systemer? Det vil jeg prøve at give et bud på med eksempler hentet fra mine kognitive analyser af magiske ritualer. De kognitive teoridannelser, jeg primært har arbejdet med i denne sammenhæng, udspringer af lingvistiske og psykologiske studier af, hvordan mennesket producerer betydning ud fra både biologisk-fysiske og sociokulturelle indtryk. Af central betydning er Lakoff og Johnson og deres teori om metafor og metonymi, der åbnede diskussionen af disse lingvistiske kategoriers kognitive fundament (Lakoff 1987; Lakoff \& Johnson 1980). Denne har direkte relevans for studiet af magi, da mange har påpeget særligt metaforens betydning i magiske ritualer. Lingvisten Roman Jakobson observerede, at Frazers klassiske beskrivelse af magi som beroende på lighed og berøring, svarer ganske nøje til den lingvistiske skelnen mellem en metafor og metonymi (Jakobson 1956). Hvor metaforen beskriver et domæne gennem et andet domæne (fx ,min elskede er en rose“, eller ,vores forhold er en gammel bil“"), beskriver metonymien et domæne gennem en del 

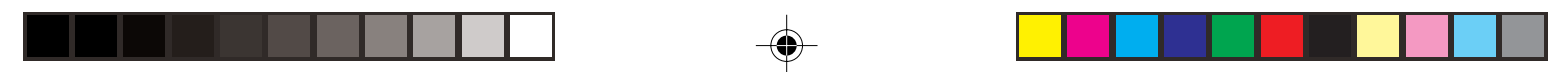

af dette domæne (fx ,,bord seks synes bøffen er for rød“, hvor bordet kommer til at stå metonymisk for den person, der spiser ved det). Ifølge Lakoff og Johnson er metaforer og metonymier helt grundlæggende kognitive mekanismer aktive i menneskets betydningsdannelse, ja det meste af vores erkendelse kan faktisk beskrives som metaforiske og metonymiske udvidelser af andre begreber. Vi bruger således lighed og del-helhed til at erkende og kategorisere verden med. Hvis disse strategier er så grundlæggende for vores erkendelse af verden og betydningsdannelse, hvad betyder det så for forståelsen af magi?

Mit udgangspunkt er således Frazers gamle distinktion, men med en ganske anden kognitiv teori som udgangspunkt. Frazer havde ret i at påpege betydningen af berøring og lighed i udførelsen af ritualer, og jeg vil søge at illustrere, at disse, plus et par andre principper, er grundlæggende for den måde, ritualer opbygges på og for den måde, hvorpå de prøver at opfylde deres funktion. Grundet omfanget vil jeg koncentrere mig om et ritual, hvis bærende element er kontagiøs berøring, mens analysen af lighedsbaserede ritualer må vente til en anden lejlighed.

Min præsentation af de metaforiske og metonymiske forbindelser i ritualer er præget af en opfølgende teoridannelse, primært udført af lingvisten Gilles Fauconnier og litteraten Mark Turner (fx Fauconnier \& Turner 1998). De adskiller sig på visse punkter fra Lakoff og Johnson, men i denne sammenhæng er det tilstrækkeligt at påpege, at de opfatter både metaforer og metonymier som en del af en mere generel teori om, hvordan mennesket blander (,,blender“) elementer, der henter deres respektive betydning fra enkelte domæner. Man skal forestille sig et mentalt rum (fx kærlighed) indeholdende bestemte elementer (forhold, passion, udvikling etc.), som forbindes til et andet mentalt rum (fx rejse) med andre elementer (transportmiddel, hastighed og rejsens mål). Visse elementer fra disse to mentale rum blandes i et nyt rum, et blend, hvis jeg for eksempel siger en sætning som „,vores forhold sidder fast.“ Et element, „,forhold“, er fra kærlighedsdomænet, mens ,,at sidde fast“" er fra rejsedomænet. Betydningen af sætningen opstår ved, at individet benytter viden om begge rum til at konstruere en ny struktur, „,blended“", med masser af indbyggede muligheder for at udvide metaforen (,,vi løb tør for benzin“, „vi må vende om“ etc.). Det blend, der produceres, er dog afhængig af, at der kan skabes forbindelser mellem elementer i de to input-rum (for eksempel mellem udvikling i et romantisk forhold og at bevæge sig over en fysisk flade, eller mellem begær og brændstof). De ligheder, der forbinder elementer fra de to rum, er afhængige af mere grundlæggende strukturer i vores kategorisering, der kan forklare, hvordan ellers forskellige elementer som benzin og begær kan gøres lig hinanden.

Her finder jeg det gavnligt at skelne mellem på den ene side kategorisering, der i denne sammenhæng skal opfattes som ubevidst, automatisk og kulturelt universel erfaring af fænomener og kræfter i verden, og på den anden side konceptualisering, der er individets mere kulturspecifikke strukturering af komplekse betydningselementer. Kategorisering kan eksemplificeres med billede-skematiske begreber som op-ned, ind-ud eller med den direkte erfaring af fysiske objekters egenskaber, som konstans, uigennemtrængelighed og manglende evne til selv at starte en bevægelse. ${ }^{3}$ Til konceptualiseringen hører begreber som „,mor“, brændstof“" og ,kærlighed“. Alle er de afhængige af og benytter aktivt elementer fra den grundlæggende kategorisering, men hvordan de konstrueres og forbindes vil have næsten uendelig kulturel variation. Mens begreberne optræder i de to input-rum og forbindes i lokale pragmatiske situationer, er basis-kategoriseringen ansvarlig for at elementer kan forbindes på tværs af rummene og på tværs af ellers grund- 
læggende forskelle. Dette er repræsenteret i det generiske rum. For eksempel kan tid næsten udelukkende forstås som en bevægelse ud af en linie, hvilket muliggør, at tiden kan opfattes som en rejse gennem rum. Da et romantisk forhold udvikler sig gennem tid, kan det forstås som en rejse, der så kan gå hurtigt, løbe ind i vanskeligheder og så videre. Begær kan på sin side opfattes som brændstoffet i et romantisk forhold, ofte forstået som en væske, der bobler op og gør mennesker utilregnelige, hvorved ligestillingen til for eksempel benzin bliver nærliggende. I dette tilfælde er forbindelsen både stoflig (væske) og dynamisk, da begge anskues som den drivende kraft bag hver deres elementer. Det generiske rum er altså fyldt med de abstrakte og skematiske egenskaber, der muliggør forskellige typer af forbindelser mellem elementer i forskellige mentale rum. ${ }^{4}$ Nedenstående figur illustrerer det blend, der fremkommer af den konventionelle metafor ,kærligheden er en rejse“:

Input rum 1: „Rejse“
a1: brændstof b1: køretøj

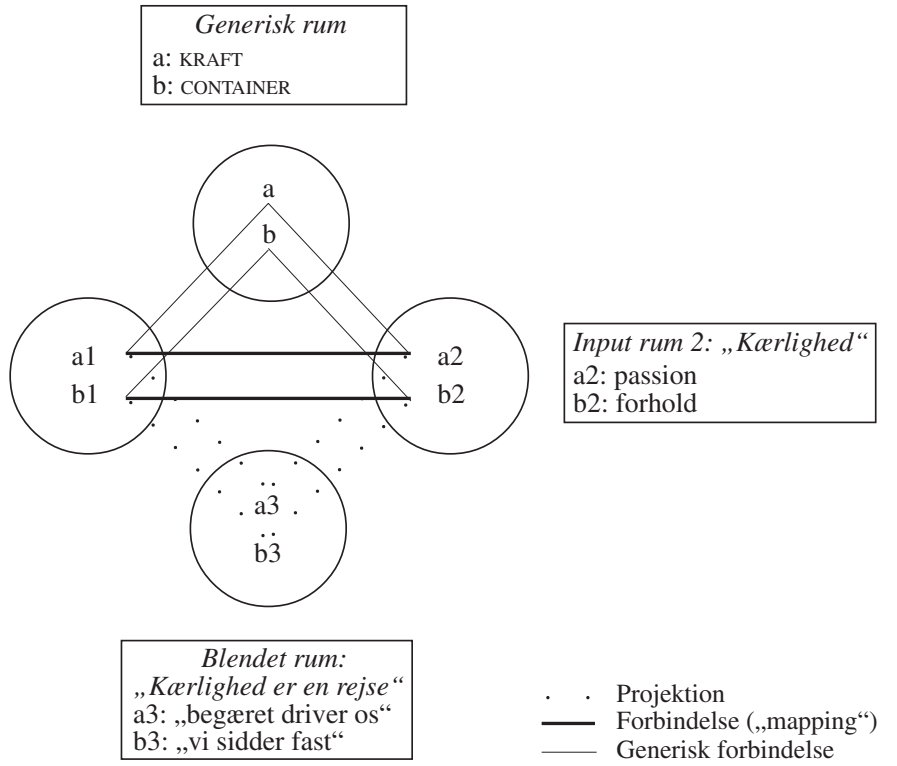

Figur 1

\section{En kognitiv tilgang til magi}

En grundlæggende forudsætning for denne tilgang er, at både magiske og religiøse ritualer kan anskues som eksempler på en sådan konceptuel blending, hvor elementer fra et sakralt domæne interagerer med elementer fra et profant domæne. Brugen af disse begreber rummer ingen bedømmelse af, hvorvidt de elementer, der er tilskrevet det sakrale domæne, findes eller ikke findes, men er blot en konstatering af, at mennesker i alle kulturer opfatter visse elementer som specielle og kraftfulde, at disse elementer bryder basale intuitive forventninger til virkeligheden (Boyer 1994), og at interaktion med dem kræver en særlig type handling, et ritual.

Som eksempel vil jeg benytte mig af det kristne nadverritual med fokus på den katolske lære om transsubstantiation og kommunion. I analysen arbejder jeg med to overordnede analytiske niveauer. Det første giver en generel beskrivelse af, hvorfra den ,,magi- 
ske agens" kommer i de enkelte ritualer og religiøse systemer. Det handler således om hvem eller hvad, der har magt til at udføre de handlinger, der findes i ritualet, det vil sige hvilken instans, der sikrer ritualets efficacitet.

I den katolske forståelse af transsubstantiationen, udført som en indledende del af nadverritualet, er præstens formelle status og liturgiens korrekte udførelse begge bærere af den magiske agens. Hvis præsten ikke er korrekt ordineret, og hvis ikke han udtaler ordene korrekt, finder den $\emptyset$ nskede handling ganske enkelt ikke sted. Dette kan illustreres på følgende måde:

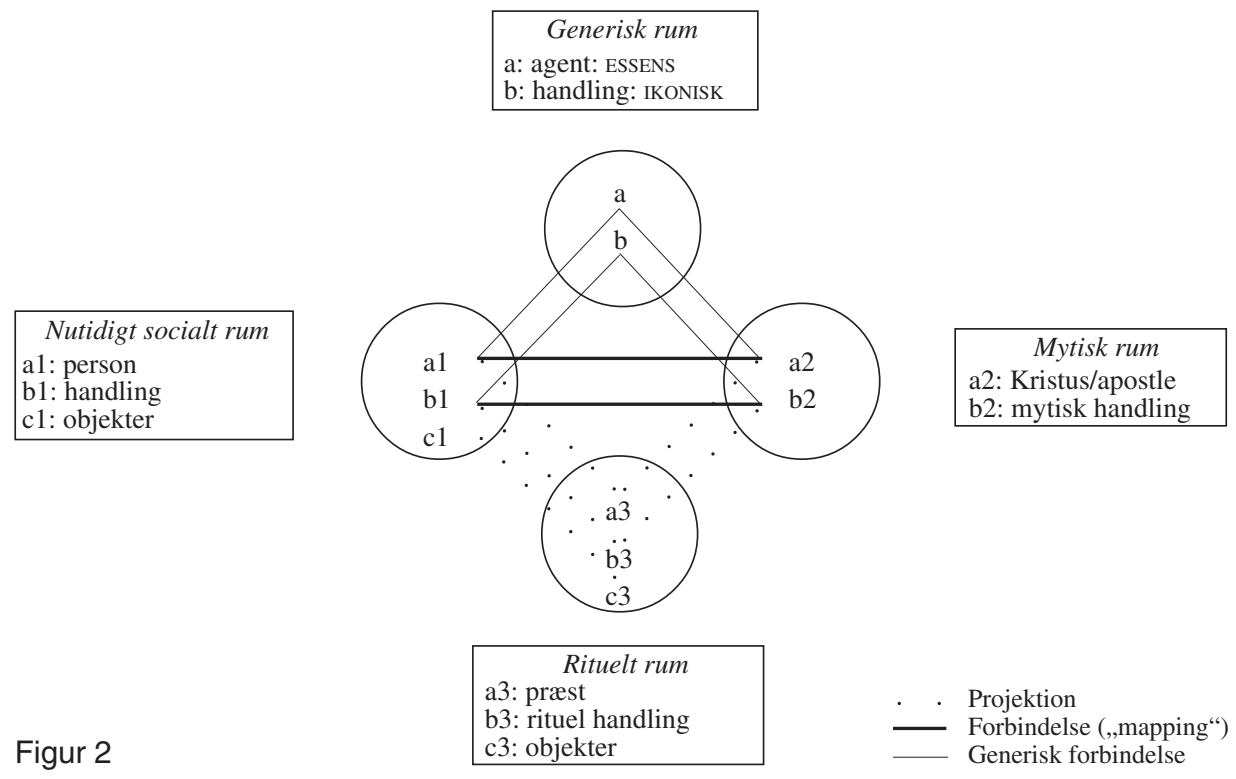

Modellen illustrerer, hvorledes elementer fra det profane rum forbindes med sakrale elementer for dernæst at projiceres ned i det blendede, rituelle rum. Handling, der udføres, bliver således kun en rituel handling, fordi den er en ikonisk reproduktion af en mytisk handling, i hvilken Kristus, i egenskab af guds søn, indstifter ritualet og giver det dets lingvistiske form. Hvis handlingen udføres forkert, er det ikke et dårligt ritual, men ritualet er slet ikke udført, handlingen projiceres ikke ned i det rituelle rum, da den ikke er identisk med den mytiske handling. Udføres handlingen derimod korrekt, er den en rituel handling, der sikrer en del af den magiske agens, som er nødvendig for, at ritualet kan tilskrives nogen efficacitet. Men den korrekte reproduktion af den mytiske handling er ikke en tilstrækkelig betingelse, de skal også udføres af den korrekte person. En person kan defineres som ,præst“, ifald han er forbundet med det sakrale domæne via den korrekte indvielse baseret på læren om apostolsk succession, der garanterer en direkte forbindelse mellem den enkelte præst og de apostolske fædre. Denne forbindelse er baseret på en ,berøringslinie“, hvor successionen er gennemført gennem håndspålæggelse, det vil sige en overførsel af essentielle egenskaber gennem berøring. Derved dannes, hvad jeg kalder en ,pseudo-genealogisk“ linie, da den efterligner repræsentationer af direkte 
blodlinie og fælles ophav, som vi finder i slægtskabsstrukturer. Men denne metonymiske forbindelse, hvor den enkelte præst er en del af en sakral helhed, er ikke tilstrækkeligt for udførelsen af transsubstantiationen. Der kræves også en mere individuel og direkte identifikation. Ifølge den katolske professor McCarthys Problems in Theology (1956) kan præsten ikke på korrekt vis gennemføre transsubstantiationsriten, hvis ikke han har den rette intentionelle indstilling. Han skal være Kristi redskab på jord, og præstens funktion er således mere end blot en formel udnævnelse; den bygger på en repræsentation af både en metonymisk forbindelse til en sakral helhed, og en delvis identitet med Kristus, der sikrer en magisk kraft til ritualets gennemførelse. Den nulevende person fungerer således som præst på grund af to forhold, der sikrer en essentiel forankret forbindelse til den mytiske figur, der indstiftede ritualet og garanterer dets fortsatte efficacitet.

Både den ikoniske reproduktion af ritens (tale-)handlinger, og præstens essentielt repræsenterede legitimitet er således nødvendige forudsætninger for, at den udførte handling er ritualet. Hverken en døvstum præst eller en ikke-ordineret talende kan udføre ritualet, hvorimod de fleste andre omstændigheder kan ændres, uden at det har direkte betydning for ritens gennemførelse.

Men hvad er det så, der sker i nadverritualets indledende fase. Jo, brødet og vinen transformeres til Jesu kød og blod, gennem den rituelle præsts korrekte fremførelse af de rituelle handlinger. Tilskrivningen af magisk agens i den rituelle ramme beskrevet ovenfor er således en forudsætning for selve ritualet, transsubstantiationen. Den spiller derfor ikke en synlig rolle i den kommende analyse, men skal tages som en forudsætning, der vil synliggøres i det fald, en af betingelserne ikke overholdes. Transsubstantiationen indebærer en mental repræsentation af magisk handling, som jeg kalder essens-blendet. Essens-blendets primære formål er at overføre essens og essentielle egenskaber mellem to forskellige elementer eller domæner. Overførslen af essens i transsubstantiationsriten er repræsenteret i den følgende model:

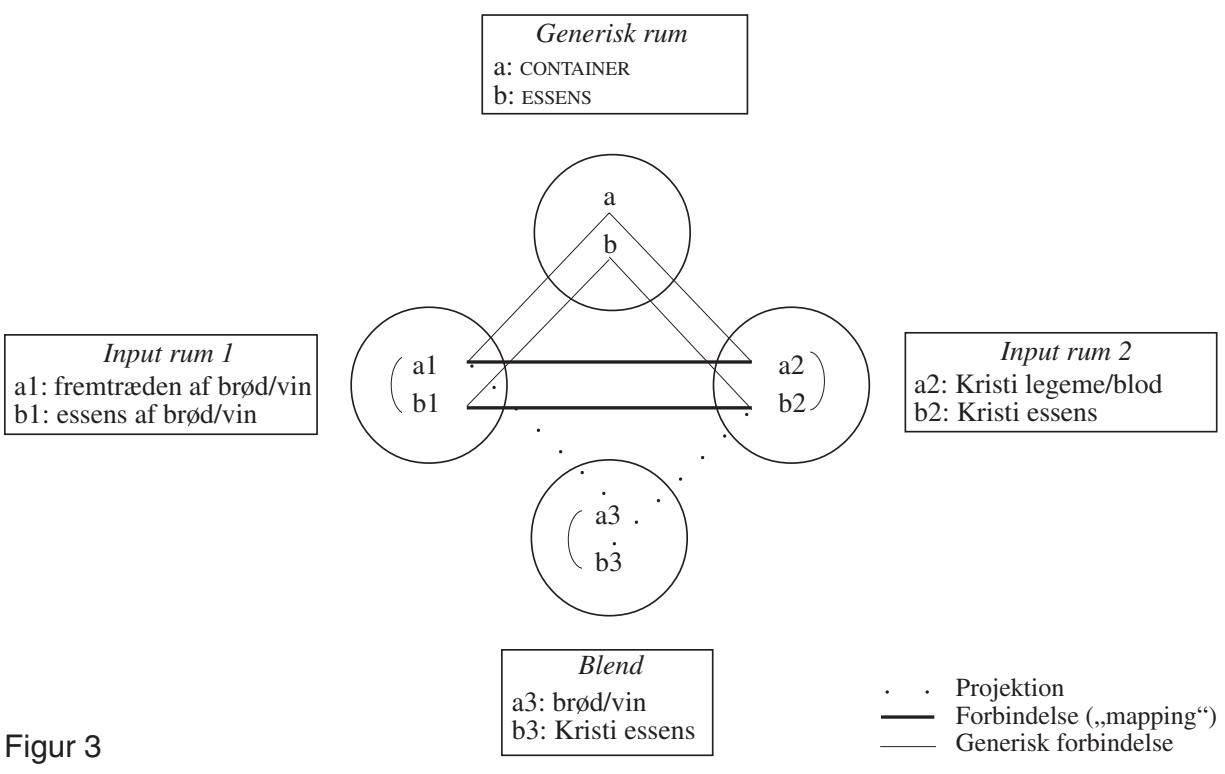



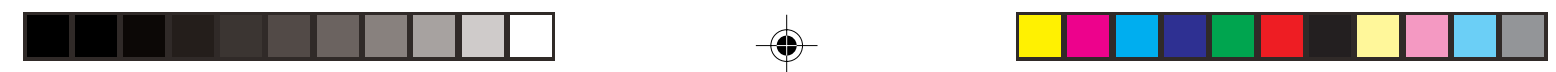

Som det fremgår, er en helt central problemstilling i dette ritual forholdet mellem Væren og Fremtræden, det vil sige mellem et objekt eller en persons fysiske udtryk og den essens, der, som en afgørende del af vores kognitive kategorisering, automatisk tilskrives alle entiteter i verden. Forholdet mellem fremtræden og væren er naturligvis et yndet tema i religion, men også i mytens, eventyrets og tryllekunstens verden, og grunden til dette er, at det benytter to grundlæggende kognitive mekanismer for kategorisering $\mathrm{i}$ verden, nemlig ydre karakteristika og indre essens. Formålet og resultatet af transsubstantiationsritualet er, at det, der på det ydre vurderes som brød og vin, opfattes som containere for Kristi essens. I ritualet forekommer en eksplicit identifikationen af brød og vin og Kristi legeme og blod. Hermed flyttes fokus fra de essentielle egenskaber, man normalt tilskriver brød og vin (,brødhed“ og „,vinhed“), og de opfattes som tomme containere. Men da brødet og vinen samtidig vedbliver med at se ud som før og altså ikke ,,ser ud" som Kristi legeme og blod, tilskrives i stedet essensen af Kristus, som så forbindes med de ydre elementer, brødet og vinen. Forbindelserne mellem brød og legeme og blod og vin beror i første omgang på, at begge kan fungere som containere for en essens, hvilket er repræsenteret i det generiske rum. Det illustreres ved det faktum, at både brødet og vinen forsat opfattes som havende Kristi essens i sig, efter ritualet er afsluttet. Containerskemaet er selvfølgelig ikke nok til i sig selv at begrunde sammenstilling brød-kød, vinblod. Ud over den overfladiske lighed er det naturligvis det mytiske forlæg, der begrunder netop denne sammenstilling. Men den bagvedliggende kognitive skematik er stadig en forudsætning for, at ritualet kan opfattes som meningsfuldt, og at det kan fortolkes, som det er foregået i nadverritualets lange og konfliktfyldte historie. Der er således to kognitive skemaer bag repræsentationen af ritualet. For det første den metaforiske forbindelse mellem brød/vin og legeme/blod, der begge er containere og som har samme fysiske karakteristika (henholdsvis fast og flydende). Dernæst den metonymiske forbindelse mellem ydre fremtræden og indre essens (buede linie). Denne sikrer, at repræsentationen af essens automatisk fremkommer gennem henvisning til ydre fremtræden, særligt $\mathrm{i}$ tilfælde hvor denne negeres af den direkte perception (det ligner jo stadig brød og vin). I transsubstantiationen projiceres den indre essens af Kristi ned i de ydre karakteristika fra brød og vin, der således fungerer som materialiserede containere for magisk agens.

Men transsubstantiationsritualet udføres jo med et ganske bestemt sigte, nemlig at overføre en ønsket essens til et materielt medium, som det er muligt at interagere med, og til hvilket adgangen kan kontrolleres og monopoliseres. Selve transsubstantiationsriten kan således opfattes som instrumentel $\mathrm{i}$ forhold til kommunionen, hvor deltagere $\mathrm{i}$ ritualet indoptager denne essens ved at spise brødet. Den rituelle agent spiller ikke nogen særlig stor rolle, da selve overførslen af essens har fundet sted, hvorved brødet på sin vis bliver den aktive kraft. Nedenstående model illustrerer, hvad der sker under indoptagelsen af brødet (se figur 4 næste side).

For deltagere i ritualet er det en forudsætning for deltagelse i kommunionen, at de er døbt og således har gennemgået et ritual, hvori deltageren „dør“ for at genopstå som et nyt menneske med del i Kristi essens og dermed, i denne artikels terminologi, får en ny essens gennem en rituel handling. I denne sammenhæng er det interessant, at det foregående ritual også indebærer en overførsel af essens gennem et materielt medium, vand, der tidligere er helliggjort gennem endnu en rituel sekvens. Dåben kan således opfattes som et indlejret ritual (Lawson \& McCauley 1990), der etablerer en varig essentiel forbindelse mellem deltageren og Kristus, som er en afgørende forudsætning for at deltage 
i kommunionen. Kommunionen kan således opfattes som et ritual, der styrker og bekræfter denne preetablerede forbindelse. Forbindelsen mellem den rituelle deltager og Kristus rummer også de skematiske forbindelser, der muliggør, at essens kan flytte sig imellem dem. Begges essens er indeholdt i en container, henholdsvis det transsubstantierede brød og deltagerens krop, hvilket muliggør, at de kan interagere med hinanden i en rituel handling. I ritualet sluger deltageren en container, brødet, der opløses og derved frigiver den essens, det har modtaget gennem transsubstantiationsritualet (i denne funktion ligger endnu en begrænsning på hvilket element, der kan tjene som container for Kristi essens - det skal kunne opløses og derved frigive sin essens). I optagelsen af essensen sker der noget interessant. Brødets essens, Kristus, transformeres nemlig til en egenskab ved deltageren, der nu kan fortolke det overførte som syndsforladelse, fornyet kraft, modstand over for sygdom og så videre. Den kvalitative ændring af deltageren er dog, i modsætning til dåbens essentielle ændring, kun midlertidig, hvorfor ritualet til stadighed skal gentages. Det er dog vigtigt at bemærke, at den symbolske fortolkning er sekundær i forhold til erfaringen af, at en eller anden overførsel rent faktisk finder sted. Hvorfor ellers spise brødet og ikke blot se på det eller forestille sig det?

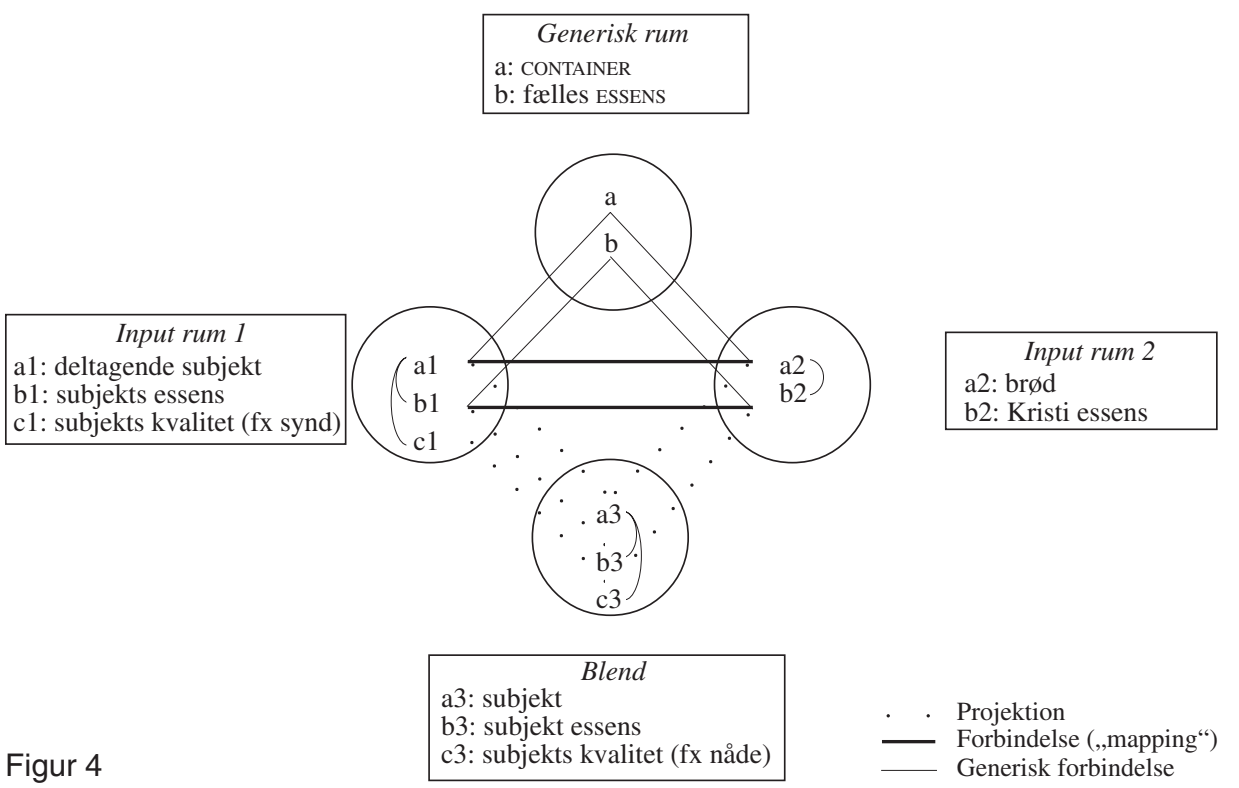

Naturligvis vil kirken som institution søge at kontrollere fortolkninger af rituelle handlinger gennem symbolsk udlægning og dogmatik, men det centrale er selve den i ritualet indbyggede grundbetydning, hvor lighed og berøring muliggør overførsel af essentielle egenskaber og på basis heraf åbner mulighed for individuelle fortolkninger påvirket af den umiddelbare kontekst, ritualet er en del af, både socialt eller individuelt. Min hypotese er, at magiske ritualer faktisk anstrenger sig for at fjerne symbolske aspekter ved de anvendte elementer, for derved at fremhæve direkte perceptuelle egenskaber som lighed og berøring. Dermed opfattes elementerne som instrumentelle, som havende en direkte 

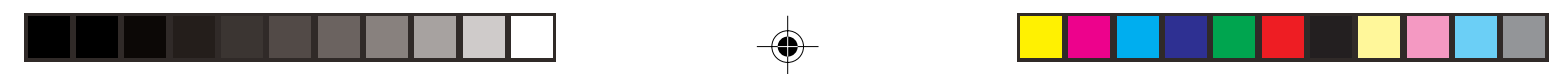

efficacitet, i stedet for den indirekte virkning i det symbolsk betydende, der forudsætter en fortolkende instans. ${ }^{5}$ „Simsalabim“ og ,abrakadabra“ er således gode at lave magi med, netop fordi deres symbolske betydning er fraværende, og de derfor kan repræsenteres som direkte virkende.

\section{Afslutning}

Som den opmærksomme læser ganske sikkert har opdaget, viser analysen ovenfor et klassisk eksempel på en kontagiøs overførsel af egenskaber gennem berøring. Psykologiske unders $\emptyset$ gelser foretaget i nutidens USA viser, at opfattelsen af både positiv og negativ besmittelse optræder spontant og naturligt hos alle mennesker (Rozin \& Nemeroff 1990), hvilket jo blot er med til at understrege, hvor grundlæggende denne måde at erfare relationen mellem elementer i verden er, uanset hvad et givent kulturelt system måtte mene er rigtig eller forkert. Jeg har andetsteds analyseret, hvad jeg kalder et skematisk blend, i hvilket overførsel af skematiske egenskaber, som for eksempel styrke, mellem to domæner er det primære formål (Sørensen 2000). Begge perspektiver er nødvendige i en mere komplet beskrivelse af magiske handlinger. Men hvordan forholder analysen sig til den indledende diskussion af magibegrebet? Jeg finder, at anvendelsen af den analytiske kategori „magi“, inspireret af klassiske teorier (fx Frazer) og sammenholdt med nyere kognitive teoridannelse, muliggør en ny tilgang til for eksempel den katolske nadver som en rituel handling. De sympatetiske forbindelser er afgørende for at give ritualet mening og efficacitet; elementer ved kategorisering beskrives som afgørende for opfattelsen af sympatetiske forbindelser mellem elementer; ritualer opfattes som instrumentelle i forhold til hinanden og den omgivende sociale og individuelle kontekst; den rituelle formalisme forklares som en af flere mulige veje at konstruere et effektivt ritual, og rituelle aktører forbindes til både mytologiske fortællinger og til socialt indstiftede positioner. Magi som begreb retter således fokus mod ritualet som en specialiseret handling, der af deltagere repræsenteres som havende en, ofte meget konkret, effekt. Som nævnt i indledningen mener jeg ikke, at det er frugtbart at konstruere en teori om magi som sådan, men jeg finder det overordentligt væsentligt at udforme teorier om de fænomener, der klassisk er beskrevet som hørende under kategorien „magi“. Mit forsvar for at bevare kategorien „magi“ er således af pragmatisk, og ikke substantiel karakter og bunder i en overbevisning om, at essentielt omstridte (Gallie 1956) og brede begreber som „,religion“, ,,videnskab“ og „magi“ har den primære funktion at rette vores opmærksomhed mod bestemte fænomener og rette undersøgelsen af disse ind i forhold til et bestemt perspektiv. At beskrive et fænomen som „,magi“ eller „,magisk“ er således ikke en forklaring, men er derimod en åbning af et sæt af spørgsmål med et bestemt, men bredt perspektiv, spørgsmål, der skal besvares gennem udformning af relevante teorier og metoder.

\section{Noter}

1. Denne artikel er en redigeret version af et foredrag holdt i Religionshistorisk Forening, Københavns Universitet d. 9. december 1999. 
2. For en diskussion af disse forhold, se Tambiah (1990). Meyer \& Mirecki (1995) er redaktører på en glimrende antologi, der belyser disse problemstillinger fra forskellige perspektiver.

3. I denne forbindelse er diskussionen af forholdet mellem domæne-specifik og domæne-generel kategorisering af central betydning. Jeg kan henvise til Hirschfeld \& Gelman (1994)

4. For en teknisk gennemgang af teorien om konceptuel blending, se Fauconnier \& Turner (1998).

5. Dette argument er tæt beslægtet med diskussion af ritualer hos Humphrey \& Laidlaw (1994).

\section{Litteratur}

Boyer, P.

1994 The Naturalness of Religious Ideas: A Cognitive Theory of Religion. Berkeley: University of California Press.

Fauconnier, G.

$1997 \quad$ Mappings in Thought and Language. Cambridge: Cambridge University Press.

Fauconnier, G. \& M. Turner

1998 Conceptual Integration Networks. Cognitive Science 22(2):133-87.

Frazer, J.

1993 The Golden Bough. [Forkortet udgave.] Hertfordshire: Wordsworth.

Gallie, W. B.

1956 Essentially Contested Concepts. Proceedings of the Philosophical Society 51.

Hirschfeld, L. A. \& S. Gelman (eds.)

$1994 \quad$ Mapping the Mind: Domain Specificity in Cognition and Culture. Cambridge: Cambridge University Press.

Humphrey, C. \& J. Laidlaw

1994 The Archetypal Actions of Ritual: A Theory of Ritual Illustrated by the Jain Rite of Worship. Oxford: Clarendon Press.

Lakoff, G.

1987 Women, Fire, and Dangerous Things: What Categories Reveal about the Mind. London: University of Chicago Press.

Lakoff, G. \& M. Johnson

$1980 \quad$ Metaphors We Live By. Chicago: University of Chicago Press.

Lawson, E. T. \& R. McCauley

1990 Rethinking Religion: Connecting Cognition and Culture. Cambridge: Cambridge University Press.

Lévi-Strauss, C.

1994 [1962] Den vilde tanke. København: Samlerens Bogklub.

Malinowski, B.

1935 The Coral Gardens and their Magic. London: George Allen \& Unwin Ltd.

Mauss, M. \& H. Hubert

1950 [1902-3] Esquisse d'une théorie générale de la magie. I: M. Mauss: Sociologie et Anthropologie. Paris: Presses Univertaires de France.

McCarthy, J. C.

1956 Problems in Theology I: The Sacraments. Dublin: Browne and Nolan Ltd.

Meyer, M. \& P. Mirecki (eds.)

1995 Ancient Magic and Ritual Power. Leiden: E. J. Brill. 
Rothstein, M

1997 Magi: Ritualtype eller social relation. Chaos: Dansk-norsk tidsskrift for religionshistoriske studier 27:41-55.

Rozin, P. \& C. Nemeroff

1990 The Laws of Sympathetic Magic: A Psychological Analysis of Similarity and Contagion.

I: Stigler, Shweder \&. Herdt (eds.): Cultural Psychology: Essays on Comparative Human Development. Cambridge: Cambridge University Press.

Sørensen, J.

1997a Magi mellem individ og samfund. Chaos: Dansk-norsk tidsskrift for religionshistoriske studier 27:21-40.

1997b Iconicity in Magic: Metaphor and Similarity in Ritual Performance. List of papers from international conference on „Image in Language and Non-language“. http://ww.hum.aau.dk/ semiotics/docs/urbino97/Soerensen.htm.

2000 Magic among the Trobrianders: Conceptual mapping in magical rituals. Almen Semiotik (under udgivelse).

Tambiah, S. J.

1990

Magic, Science, Religion, and the Scope of Rationality. Cambridge: Cambridge University Press.

Taussig, M

1994

Mimesis and Alterity: A Particular History of the Senses. New York: Routledge. 
